\title{
Thermal and radiation environments for assessing crop-weather relationship of soybean in eastern Madhya Pradesh
}

\author{
MANISH BHAN ${ }^{\dagger}$, DESHRAJ PATEL, L. D. WALIKAR, P. VIJAYA KUMAR ${ }^{1}$ and K.K. AGRAWAL \\ Jawaharlal Nehru Krishi Vishwa Vidyalaya, Jabalpur 482 004, Madhya Pradesh \\ ${ }^{1}$ ICAR-Central Research Institute for Dryland Agriculture, Santoshnagar, Hyderabd 500 059, Telangana \\ Corresponding author : bhan.manish@gmail.com
}

\begin{abstract}
A field experiment was conducted during with three sowing dates (23 June, 8 July and 23 July) with three varieties (JS 20-29, JS 20-34 and JS 97-52) kharif season of 2016 and 2017 at Jabalpur in eastern Madhya Pradesh for assessing crop weather relationship in soybean through thermal and radiation environments. The results revealed that early sown crop attained more accumulated heat units, and yield decreased with delay in sowing. The maximum and minimum temperatures during reproductive stage were positively correlated with seed yield while negatively associated with vegetative and pod development stages. Photosynthetic active radiation absorption (APAR) was maximum in June sowing in semi-determinate JS 97-52 variety at pod formation stage. Maximum leaf area index (LAl) exhibited in June sown for JS 97-52 variety during pod formation stage. Seed yield increase with increased in APAR and LAI during pod formation stage. Season length difference between normal and actual crop maturity period increased with the decrease in GDD thereby suggesting a decline in yield due to shortening of crop growing period.
\end{abstract}

Keywords: Weather parameters, soybean, GDD, APAR, LAI, season length, correlation, regression.

Soybean (Glycine max (L.) Merrill) ranks first among the oilseeds in the world and has a prominent place in India. Area under its cultivation was nearly 101 lakh ha in 201617 with production and productivity of 84 lakh MT and 822 $\mathrm{kg} \mathrm{ha}^{-1}$ (SOPA, 2018). Madhya Pradesh occupies an area and production of 49 and 50.3 per cent of a total national average. Weather variables like temperature, sunshine hours, radiation, etc has its requirement to attain optimum yield, and these requirements may vary from variety to variety within a species (Sattar et al., 2017). A variation in photoperiod and temperature influenced growth and development stages, and partitioning of dry matter in this crop(Lawn 1989). With the help of crop-weather relationship studies, it is possible to judge the influence of weather parameters on growth and seed yield. Jeyaraman et al. (1990) stated that the production potential of soybean can be enhanced with maximum temperature of $31.2 \pm 31.6^{\circ} \mathrm{C}$ and minimum temperature of $20.4 \pm 20.9^{\circ} \mathrm{C}$. Similarly, crop growth is also determined by solar radiation intercepted by the canopy with the genetic characteristics (van Ittersum and Rabbinge, 1997). The reduction in photosynthetic active radiation (PAR) hampers the yield of photo-sensitive crops like soybean (Bhagat et al., 2017), hence its effect on soybean in subtropical environment needs to be studied.
Additionally, ecophysiological factors like leaf area index (LAI) are a potential factor in defining yield in the subtropics where varieties are sown in a broad range of maturity groups. LAI is a useful indicator of foliage development, and influenced by both abiotic and biotic factors; thus, achievement of optimum LAI favors in reducing yield gaps in soybean production (Tagliapietra et al., 2018). Therefore, it is useful to identify parameters affecting growth and seed yield at different phenophase; and also to assess the optimum weather conditions for maximizing its production in eastern Madhya Pradesh.

\section{MATERIALS AND METHODS}

A field experiment was conducted during kharif season of 2016 and 2017 at research farm of Jawaharlal Nehru Krishi Vishwa Vidyalaya, Jabalpur (Latitude: $23^{\circ} 09$ N, Longitude: $79^{\circ} 53 \mathrm{E}$, Altitude: $411 \mathrm{~m}$ ) of eastern Madhya Pradesh. The soil is clay in texture and vertisol in order. The average annual rainfall is $1358 \mathrm{~mm}$ of which 90 per cent rainfall is received during kharif season. The experiment was laid in a split plot design having three staggered dates of sowing (23 June, 8 July, 23 July) with three varieties viz., JS 20-29 (semi-determinate medium maturing in 95 days), JS 20-34 (determinate extra early maturing in 85-87 days), JS 
97-52 (semi-determinate late maturing in 98-102 days). These varieties were resistant to major pests and diseases in soybean. They were sown under rainfed conditions on broad bed furrow system, and adequate plant protection measures were adopted. The distance between two bedcentre was $75 \mathrm{~cm}$ while width of single bed as $50 \mathrm{~cm}$ with a row distance within bed was $45 \mathrm{~cm}$. The crop was uniformly fertilized with $20 \mathrm{~kg}$ of N, $60 \mathrm{~kg}$ of $\mathrm{P}_{2} \mathrm{O}_{5}$ and $30 \mathrm{~kg}$ of $\mathrm{K}_{2} \mathrm{O}$ per hectare, and seeds were inoculated with Rhizobium leguminsorum, and treated with Thiomethoxam $30 \mathrm{FS}$ (10 $\mathrm{g} \mathrm{kg}^{-1}$ seed) prior to sowing, respectively. Standard agronomic practices for weed and insect control were practiced uniformly to maintain plots free from biotic stress. The occurrence of phenological events like emergence, branching, flowering and maturity were recorded from each plot and average dates of these phases were calculated and used for analysis. The daily weather data of the growing season were collected from nearby agromet observatory located at Jabalpur. The accumulated Growing-Degree-Day (GDD) or heat unit was worked out for different phases of growth using the following equation (Nuttonson 1995)

$\mathrm{GDD}=\Sigma\left[\left(\mathrm{T}_{\max }+\mathrm{T}_{\min }\right) / 2\right]-\mathrm{T}_{\mathrm{b}}$

Where $\mathrm{T}_{\max }$ is the maximum temperature of the day in ${ }^{\circ} \mathrm{C}$

$\mathrm{T}_{\min }$ is the minimum temperature of the day in ${ }^{\circ} \mathrm{C}$

$\mathrm{T}_{\mathrm{b}}$ is base temperature in ${ }^{\circ} \mathrm{C}$ as $10^{\circ} \mathrm{C}$

The correlation coefficient was worked out between soybean yield and weather parameters at different phenophases of the crop. The best fit regression equation between soybean yield and both the temperatures at different phases of growth were developed to examine the soybeanweather relationship.

The absorbed photosynthetic active radiation (APAR) was measured using line quantum sensor (LI-191 SB, LICOR Inc., NE, USA) at flower initiation, pod formation and physiological maturity stages two times in a plot utilizing four components as.

$$
\mathrm{APAR}=(\mathrm{PAR}+\mathrm{RPAR})-(\mathrm{TPAR}+\mathrm{RPAR})
$$

The portion of the incident photosynthetic active radiation (PAR), which transmit through the plant canopy to the soil surface (TPAR) will have a portion reflected by the soil (RPAR) back into the plant canopy. Similarly, leaf area was measured at flower initiation and pod formation stages using leaf area meter (CI-202, CID BIo-Sci., WA, USA) of flat leaves of three plants per plot. Later, it was averaged as one and multiplied with the number of plants covering a ground area of a sq. metre to analyze leaf area index (LAI).

The relation between GDD and difference in season length (days) was derived between normal length (period average of 10 years from sowing to maturity) and actual crop growing period of 2016 and 2017 years.

\section{RESULTS AND DISCUSSION}

\section{Phenophase duration and accumulated heat unit requirement}

The duration of phenological stages and heat unit required are based on two-year observations are presented in the Tables1. There was a variation under different microenvironmental conditions at different phenophase (Table 1). The results indicated that more duration is needed of either vegetative (emergence to flower initiation), flowering (flower initiation to pod initiation) and pod development (pod initiation and maturity) stages in the first date (which may be considered as a normal sowing window) while the remaining sowing windows represent late sowing of the crop. The crop sown on 23 July require one day less to attain flowering stage than that sown on 23 June. Similar trend was revealed at pod development stage. The crop sown at normal time attain maturity in 90 days, while crop sown late reached maturity in 84 and 79 days, respectively. Being thermo-sensitive and short day plant, sowing time affect phenology of the crop from adoption to the time of maturity (Kumar and Badiyala, 2005). Variation in phenophase duration caused by changes of sowing dates, which led to early or delayed fulfillment of thermal requirements to attain a particular phenological stages (Sattar et al., 2017).

Accumulated GDD was computed at different phenophase of crop growth stages (Table 1). The normal sown crop accumulated maximum GDD to reach various phenophases $\left(1521{ }^{\circ} \mathrm{C}\right.$ day) followed by 23 July sowing ( $1419^{\circ} \mathrm{C}$ day). Crop sown on 8 July availed less GDD among all the phenophase than crop sown on 23 July. Shankar et al., (1996) revealed that GDD requirements were more under early sown soybean. Among soybean varieties, JS 9752 attain more GDD ( $1629^{\circ} \mathrm{C}$ day) followed by JS 20-29 ( $1395^{\circ} \mathrm{C}$ day) and JS 20-34 (1283 ${ }^{\circ} \mathrm{C}$ day) to reach maturity. Soybean cv. JS 97-52 as a long- duration variety, and needs more time to mature, it requires more heat units for completing life cycle. Similarly, June sown crop availed more time of hot summer months than July sown crop, and hence accumulate more thermal time, as also suggested by Singh et al. (2007) in soybean. 
Table 1: Phenophase duration and accumulated growing degree-day requirements of soybean varieties at different sowing

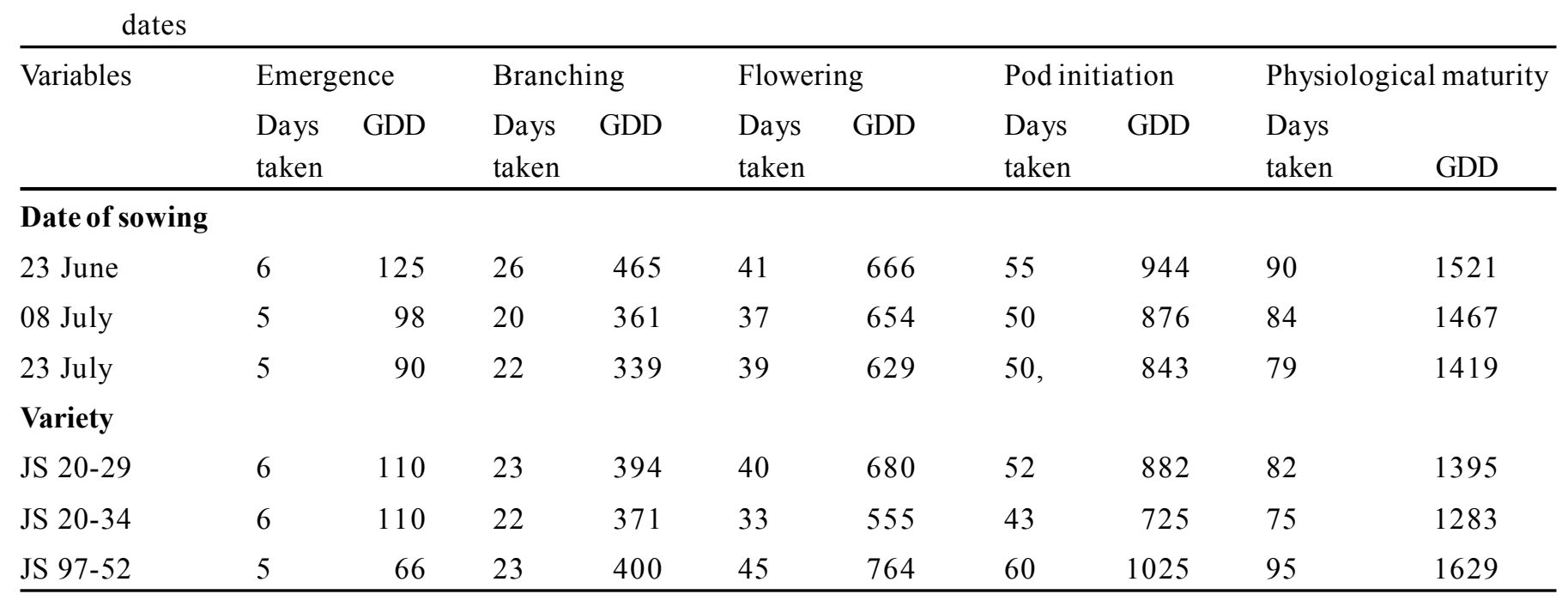

Table 2: Correlation coefficients of weather parameters with seed yield at different phenophases in soybean

\begin{tabular}{lllll}
\hline Weather Parameter & Emergence & Flower initiation & Pod initiation & Physiological maturity \\
\hline Maximum temperature & $-0.501^{*}$ & $0.631^{*}$ & $-0.719^{*}$ & -0.139 \\
Minimum temperature & $-0.599^{*}$ & $0.572^{*}$ & -0.932 & 0.033 \\
Sunshine hours & -0.272 & 0.834 & -0.235 & 0.128 \\
\hline
\end{tabular}

* Significance at $5 \%$ level

\section{Seed yield-temperature relationship}

A correlation analysis between weather parameters and seed yield exhibit a significant negative correlation of minimum temperature and seed yield at emergence, however both the temperatures indicates a significant positive correlation exhibit during flower initiation stage (Table 2). Except at flower initiation, maximum temperature exhibit negative correlation with seed yield. The bright sunshine hours reveals a positive correlation with seed yield during flower initiation and maturity stage. An increase in both the temperatures and sunshine hours during flower initiation may improve seed yield, while increase of these weather parameters during pod initiation may hamper seed yield. Identification of critical weather variables and their quantification at different phenophases is essential for successful crop production (Sattar et al., 2017). Additionally, rainfall also plays a major role in seed yield, as water stress condition during flower and pod growth stages combined with significantly higher heat units considerably slowed down the potential reproductive growth leading to poor biomass production and low seed yield (Lal et al; 1999).

A linear relationship between seed yield and temperature were obtained in the present study. Maximum and minimum temperatures were used in equation as they showed a significant relationship with seed yield at different phenophase of crop growth. The equations at different phenological growth stages as:

(a) Sowing to emergence:

$\mathrm{Y}=193 \mathrm{~T}_{\min }-3181.5 ; \mathrm{R}^{2}=0.65 ; \mathrm{n}=16 ; \mathrm{P}=0.001$

(b) Emergence to flowering:

(i). $\mathrm{Y}=1351.8 \mathrm{~T}_{\text {min }}-30574 ; \mathrm{R}^{2}=0.56 ; \mathrm{n}=16 ; \mathrm{P}=0.004$

(ii). $\mathrm{Y}=532.8 \mathrm{~T}_{\max }-14577 ; \mathrm{R}^{2}=0.41 ; \mathrm{n}=16 ; \mathrm{P}=0.03$

(c) Flowering to pod initiation:

$\mathrm{Y}=75.3 \mathrm{~T}_{\max }-824.7 ; \quad \mathrm{R}^{2}=0.53 ; \mathrm{n}=16 ; \quad \mathrm{P}=0.006$

Variation of seed yield using different regression equations exhibited that about 65 and 56 per cent variation in seed yield can be explained by minimum temperature $\left(\mathrm{T}_{\text {min }}\right)$ from sowing to flowering stages. Similarly, variation in seed yield by 41 and 53 per cent can be explained by maximum temperature $\left(\mathrm{T}_{\max }\right)$ from emergence to flowering, and flowering to pod initiation stages.

\section{APAR - seed yield relationship}

The variation in APAR at different phenological stages among sowing dates of soybean varieties is presented in Table 3. Maximum PAR absorption exhibited at pod initiation during both the years. Among sowing dates, PAR absorbed maximum during June sowing, except at flower initiation 
Table 3: Absorbed PAR (APAR) at different phenological stages of soybean varieties at different sown dates

\begin{tabular}{|c|c|c|c|c|c|c|}
\hline \multirow[t]{2}{*}{ Treatments } & \multicolumn{3}{|c|}{$\operatorname{APAR}\left(\mathrm{MJ} \mathrm{m}^{-2}\right)$ in 2016} & \multicolumn{3}{|c|}{$\operatorname{APAR}\left(\mathrm{MJ} \mathrm{m}^{-2}\right)$ in 2017} \\
\hline & $\begin{array}{l}\text { Flower } \\
\text { initiation }\end{array}$ & $\begin{array}{l}\text { Pod } \\
\text { initiation }\end{array}$ & $\begin{array}{l}\text { Physiological } \\
\text { maturity }\end{array}$ & $\begin{array}{l}\text { Flower } \\
\text { initiation }\end{array}$ & $\begin{array}{l}\text { Pod } \\
\text { initiation }\end{array}$ & $\begin{array}{l}\text { Physiological } \\
\text { maturity }\end{array}$ \\
\hline \multicolumn{7}{|c|}{ Dates of sowing } \\
\hline 23 June & 279.7 & 466.9 & 312.0 & 399.8 & 537 & 263.6 \\
\hline 08 July & 327.5 & 433.7 & 291.5 & 421.1 & 535 & 370.9 \\
\hline 23 July & 214.8 & 267.7 & 286.6 & 219.5 & 258.4 & 277.4 \\
\hline \multicolumn{7}{|l|}{ Varieties } \\
\hline JS 20-29 & 385.5 & 438.6 & 380.7 & 321.8 & 444.9 & 369.3 \\
\hline JS 20-34 & 216.6 & 364.1 & 189.6 & 299.5 & 383.3 & 262.0 \\
\hline JS 97-52 & 328.9 & 484.4 & 378.8 & 419.1 & 502.0 & 280.7 \\
\hline
\end{tabular}

stage where 08 July exhibited higher APAR than sown during June. Among the varieties, absorption of PAR increases from flower initiation and reaches maximum during pod initiation stage. After then, it decline at physiological maturity stage (Table 3). Both JS 20-29 and JS 97-52 varieties are semi-determinate genotype that absorbs more PAR than determinate JS 20-34 variety. Soybean is a photosensitive crop and needs a specific PAR range (800-1200 PAR $\mu \mathrm{mol}^{-1} \mathrm{~m}^{-2} \mathrm{~s}^{-1}$ ) for photosynthesis beyond which its production is affected drastically (Bhagat et al., 2017).

A linear relationship between seed yield and APAR at pod formation stage is presented in the Fig. 1. The result at flower initiation was not significant $\left(\mathrm{R}^{2}=0.077\right)$ hence not considered. At pod formation stage, a positive relationship suggest an increase in seed yield with an increase in absorption of PAR. A 72 per cent variation in seed yield through PAR exhibited in soybean. A determinate genotype exhibited fewer light saturation point and photosynthetic rate than semi-determinate genotype (Bhagat et al., 2017). As this rate is directly proportional to yield, hence semi-determinate genotypes will perform better under future PAR scenario of more concentration of aerosols with increase in the number of cloudy days.

\section{LAI - Seed yield relationship}

A variation in LAI during flower and pod initiation stages is presented in Table 4. LAI was not observed during physiological maturity stage as leaves were dry and desiccated. Among sowing dates, maximum LAI exhibited during June sowing followed by 08 July and 23 July sown dates. Among phenological stages, pod initiation exhibited 62-70 per cent more LAI than at flower initiation stages. Among the varieties, JS 97-52 exhibited higher LAI at both the phenological stages followed by JS 20-29 and JS 20-34
Table 4: Leaf area index of soybean varieties influenced by sowing dates at different time intervals

\begin{tabular}{lllll}
\hline Treatments & \multicolumn{2}{c}{ LAI (2016) } & \multicolumn{2}{c}{ LAI (2017) } \\
& $\begin{array}{l}\text { Flower } \\
\text { initiation }\end{array}$ & $\begin{array}{l}\text { Pod } \\
\text { initiation }\end{array}$ & $\begin{array}{l}\text { Flower } \\
\text { initiation }\end{array}$ & $\begin{array}{l}\text { Pod } \\
\text { initiation }\end{array}$ \\
\hline Dates of sowing & & & \\
23 June & 1.48 & 5.18 & 1.44 & 4.55 \\
08 July & 1.40 & 4.08 & 1.42 & 3.98 \\
23 July & 1.35 & 3.60 & 1.35 & 3.31 \\
Varieties & & & & \\
JS 20-29 & 1.42 & 4.34 & 1.41 & 4.07 \\
JS 20-34 & 1.34 & 3.80 & 1.31 & 3.65 \\
JS 97-52 & 1.49 & 4.74 & 1.49 & 4.13 \\
\hline
\end{tabular}

varieties. Both semideterminate varieties achieved more LAI than a determinate JS 20-34 variety. Varieties with long maturity period achieved more LAI than short maturity period. Similarly, LAI decrease with delay in the sowing dates, regardless of maturity period and growth habit (Tagliapietra et al., 2018). The pod formation period coincide with maximum LAI, as redistribution of nutrients, and other compounds from senescent leaves, branches and stem to the grains (Mundstock and Thomas, 2005). Additionally at pod filling period, higher LAI ensures maximum interception of solar radiation for grain formation.

A linear relationship between seed yield and LAI at pod formation stage is presented in the Fig. 2 . The results at flower initiation stage is not significant $\left(\mathrm{R}^{2}=0.39\right)$ hence not considered. At pod formation stage, a positive relationship exist between LAI and seed yield with 82 per cent variation in seed yield due to LAI at this stage in soybean. 


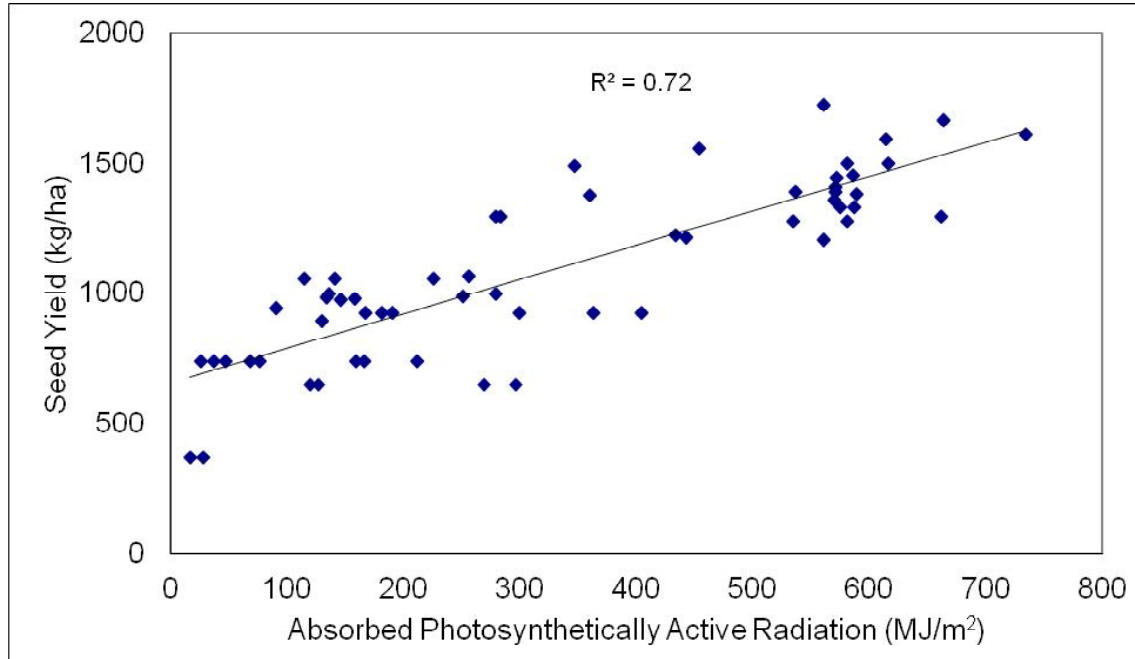

Fig. 1: Association between seed yield and photosynthetic active radiation (APAR) in soybean during pod formation stage in kharif 2016 and 2017 seasons

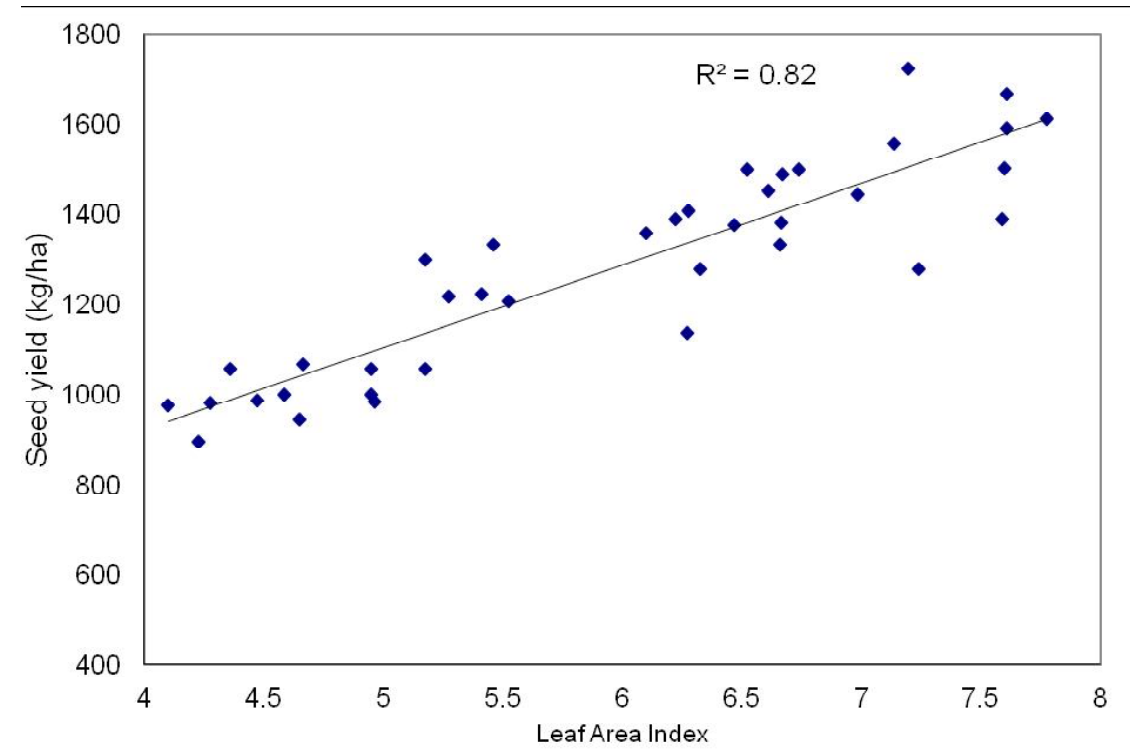

Fig. 2: Association between seed yield and leaf area index at pod formation stage in soybean

\section{GDD-Season length relationship}

A simple plot to illustrate a relationship between accumulated GDD and difference in season length is presented in Fig. 3. The effect of temperature on maturity was assessed using regression analysis. It observed increase in GDD if difference between actual and normal crop growing period is less. On the contrary, GDD will get skewed with the increase in difference of crop growing period. A day length in crop growing period influences the rate of development. A delay in sowing shortens crop maturity period, and accelerate senescence causing damage to photosynthetic cells that reduce photosynthetic rate thereby affecting crop productivity (Al-Khatib and Pavlsen 1999).

\section{Seed yield among sowing dates and varieties}

Seed yield under different thermal environments and varieties is presented in Fig. 4. During the year 2016, maximum seed yield was observed on 23 June (1289 kg ha $\left.{ }^{1}\right)$ followed by 8 July $\left(1111 \mathrm{~kg} \mathrm{ha}^{-1}\right)$ however it reduced in 23 July ( $542 \mathrm{~kg} \mathrm{ha}^{-1}$ ) sown crop. The trend was similar in 2017 year. Among the varieties, JS 97-52 exhibited maximum seed yield (1035 and $1325 \mathrm{~kg} \mathrm{ha}^{-1}$ ) followed by JS 20-29 and JS 20-34 varieties in both the years. Bhatia et al. (2008) observed that maximum seed yield of soybean was obtained with June 20 sowing, and marginally declined as sowing was 


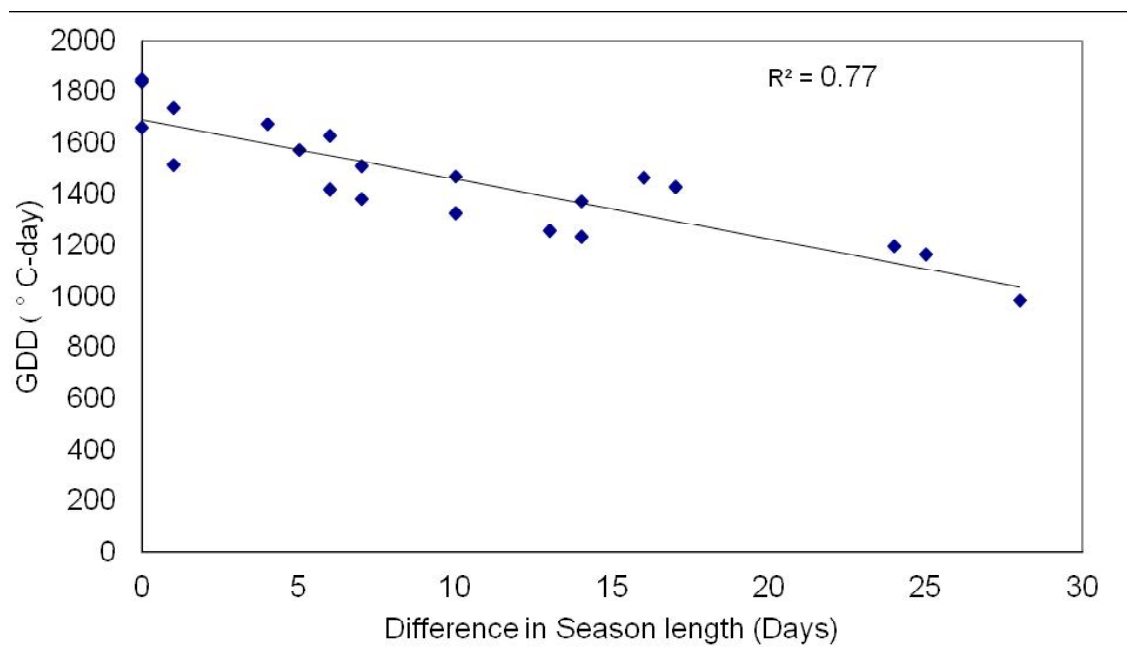

Fig. 3: Effect of growing degree day on growing length difference of soybean

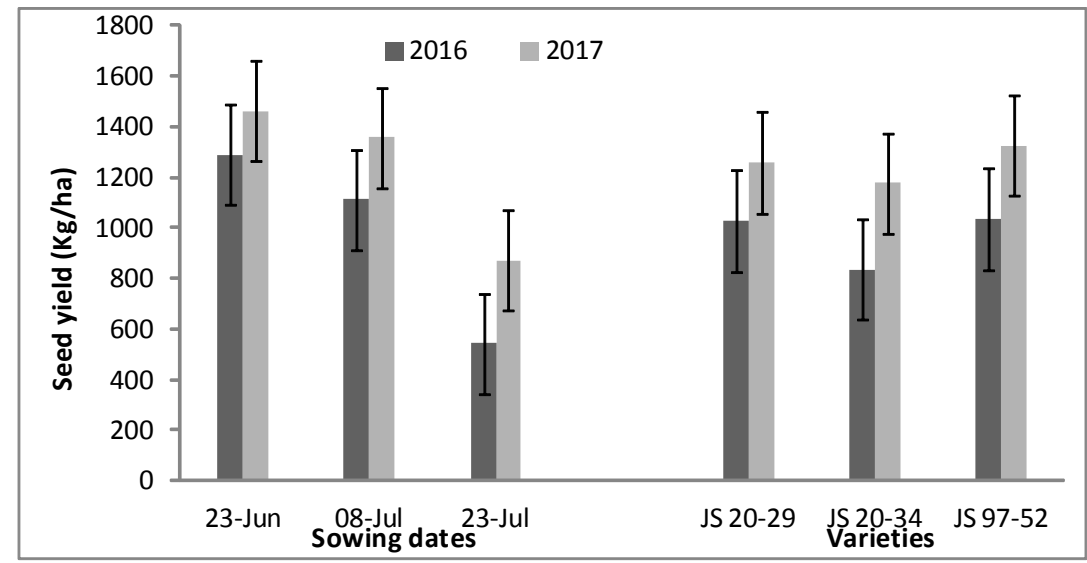

Fig.4: Impact of date of sowing on seed yield of different soybean varieties

delayed till 10 July. Seed yield declined sharply if sown beyond $10 \mathrm{July}$. In early sowing there was a sufficient time for the variety to exploit the soil and environmental resources for their vegetative development compared to late sowing that shortens the crop duration (Shah et al. 1999). Additionally, more solar radiation is available for early sown crop that favors yield.

\section{CONCLUSIONS}

On the basis of two-year field experiment, it is concluded that accumulated heat units was highest under long duration semi-determinate variety in early sown (June sown) crop. Correlation analysis revealed that maximum temperature during vegetative and reproductive stage of crop growth influenced seed yield. Both the temperatures during flower initiation phase played a major role thereby affecting seed yield. High temperature during pod development stage results in lowering yield in delayed sown crop. Variation in PAR absorption was maximum during pod initiation stage during June sowing in semi-determinate JS 97-52 and JS 20-29 varieties. Similarly, maximum LAI exhibited during pod initiation stage in June sowing for semi-determinate JS 97-52 variety. Increase in both APAR and LAI during pod formation increase seed yield of soybean. A decrease in GDD observed with an increase in season length difference between normal and actual crop maturity period. Highest seed yield was obtained when crop was sown during June, which declined sharply if sown after the first week of July in both the years.

\section{ACKNOWLEDGEMENTS}

The study was conducted under the All India Coordinated Research project on Agrometeorology (ICAR) operated under Jawaharlal Nehru Krishi Vishwa Vidyalaya, Jabalpur. The authors are thankful to ICAR-CRIDA Hyderabad for providing technical and financial assistance to undertake this study. 


\section{REFERENCES}

Al-Khatib, K. and Paulsen, G.M. (1999). High-temperature effects on photosynthetic processes in temperate and tropical cereals. Crop Sci., 39:119-125.

Bhagat, K.P., Bal, S.K., Singh, Y., Potekar, S., Saha, S., Ratnakumar, P., Wakchaure, G.C. and Minhas, P.S. (2017). Effect of reduced PAR on growth and photosynthetic efficiency of soybean genotypes. J. Agrometeorol., 19:1-9.

Bhatia, V. S., Singh, P., Wani, S.P., Chauhan, G. S., Kesava Rao, A. V. R., Mishra, A. K. and Srinivas, K. (2008). Analysis of potential yield and yield gap of rainfed soybean in India using CROPGRO-Soybean model. Agric. Forest Meteorol., 148:1252 - 1265.

Jeyaraman S., Subramaniam, S. and Rangaswami, S.R. (1990). Influence of weather parameters at crop growth stages on seed yield of soybean. Mausam, 41: 575-578.

Kumar, J. and Badiyala, D. (2005). Effect of seed rate, row spacing and sowing time on yield attribute of soybean. Legume Res., 28:288-290.

Lal, M., Singh, K. K., Srinivasan, G., Rathore, L. S., Naidu, D. and Tripathi, C. N. (1999). Growth and yield responses of soybean in Madhya Pradesh to climate variability and change. Agric. Forest Meteorol., 93: 53-70.

Lawn, R. J. (1989). Agronomic and physiological constraints to the productivity of tropical grain legumes and prospects for improvement. Exptl. Agric., 25:509-528.

Mundstock, C.M. and Thomas, A.L. (2005). Soybeans: Factors affecting the growth and grain yield. Porto Alegre, Departamento de Plantas de Lavoura da Universidade Federal do Rio Grande do Sul, Evangraf.
Nuttonson, M. Y.(1955). Wheat-climatic relationships and the use of phenology in ascertaining the thermal and photothermal requirements of wheat. American Institute of Crop Ecology. Washington, D.C. pp. 54-55.

Sattar, A., Kumar, M., Kumar, P. V. and Khan, S.A.(2017). Crop weather relation in kharif rice fornorth westalluvial plain zone of Bihar. J. Agrometeorol., 19:71-74.

Shankar, U., Agrawal, K.K. and Gupta, V.K. (1996). Heat unit requirement of rainfed soybean $(\operatorname{Glysinemax}(\mathrm{L})$. Merrill). Indian J. Agric. Sci., 66: 401-404.

Shah, S.M.,Aslam, M., Shafiq, S. and Aslam, M.H.(1999). Effect of sowing dates and row spacing on soybean yield and yield components in autumn under rainfed conditions. Pakistan J. Botany, 31: 103-108.

Singh, A., Rao, V.U. M., Singh, D. and Singh, R. (2007). Study on agrometeorological indices for soybean under different growing environments. J. Agrometeorol., 9(1): 81-85.

SOPA, (2018). The soybean processors association of India. Available at www.sopa.org.

Tagliapietra, E.L., Streck, N.A., Rocha, T.S.M., Richter, G.L., Silva, M.R., Cera, J.C., Guedes, J.V.C. and Zanon, A.J. (2018)Optimum leafarea index to reach soybean yield potential in subtropical environment. Agron. J., 110:932938.

van Ittersum, M.K. and Rabbinge, R. (1997). Concepts in production ecology for analysis and quantification of agricultural input-output combinations. Field Crop Res., 52:197-208. 